YEARBOOK

of ANTITRUST

and REGULATORY

STUDIES

www.yars.wz.uw.edu.pl
Peer-reviewed scientific periodical, focusing on legal and economic issues of antitrust and regulation. Creative Commons Attribution-No Derivative Works 3.0 Poland License.

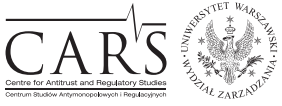

Centre for Antitrust and Regulatory Studies, University of Warsaw, Faculty of Management www.cars.wZ.uw.edu.pl

\title{
Directive (EU) 2019/1 as Another Brick into Empowerment of Slovak Market Regulator
}

\author{
by
}

Hana Kováčiková*

\section{CONTENTS}

I. Introduction

II. Safeguards: State-of-the-art situation in Slovakia

III. Conflict of interest in Antitrust law

IV. Effective enforcement?

V. Conclusion

\section{Abstract}

The paper analyses the legal challenges brought to the Slovak competition law by Directive (EU) 2019/1 of the European Parliament and of the Council of 11 December 2018 to empower the competition authorities of the Member States to be more effective enforcers and to ensure the proper functioning of the internal market. The author selected particular issues from Slovak competition law and compares the state-of-the-art national situation with corresponding parts of this harmonising act. In the paper, specific attention will be given to compliance with safeguards, to the regulation of conflict of interest, to the examination of the effectiveness of enforcement, and to the possibilities of undertakings to avoid their responsibility for the breach of competition law. As the Member States have time for the transposition until 4 February 2021, this paper may initiate the debate on what to improve in Slovak legislation to achieve the goals set in this Directive.

* Assistant professor at Faculty of Law, Comenius University in Bratislava; hana. kovacikova@flaw.uniba.sk, ORCID: 0000-0002-4158-0924. The paper was prepared within project VEGA No 2/0167/19 (2019-2022) 'The Real Convergence in the European Union: Empirical Evidence and Implications' . Article received: 13 June 2019; accepted: 23 July 2019. 


\section{Résumé}

Larticle analyse les défis juridiques qui ont été soumis au droit slovaque de la concurrence par la directive (UE) 1/2019 afin d'habiliter les autorités de concurrence des États membres à mieux faire respecter les règles et à assurer le bon fonctionnement du marché intérieur. Lauteur a choisi des questions particulières du droit slovaque de la concurrence et il compare la situation nationale actuelle avec les éléments correspondants de la présente loi d'harmonisation. Dans cet article, une attention particulière est accordée au respect des garanties, à la réglementation des conflits d'intérêts, à l'examen de l'efficacité de l'application et à la possibilité pour les entreprises d'éviter leur responsabilité en cas de violation du droit de la concurrence. Du fait que les États membres ont jusqu'au 4 février 2021 pour transposer la directive, le présent article peut lancer le débat sur les améliorations à apporter à la législation slovaque pour concrétiser les objectifs fixés dans cette directive.

Key words: competition law, Antimonopoly Office, safeguards, principle of good administration, right to the defence, right to be heard, right to access the file, conflict of interest, effectivity, enforcement, avoidance of responsibility.

JEL: K2, K21

\section{Introduction}

Functioning competition is one of the tools how to achieve an operational internal market within the European Union. Respecting competition rules by market players is therefore crucial. However, the presumption of full compliance of undertakings with competition rules is unrealistic. Just for example, the official cartel statistics ${ }^{1}$ provided by the European Commission showed that in the period 2015 - (16 May) 2019, the Commission has adopted 25 cartel case decisions and imposed fines of a total amount of $8254783753 €^{2}$.

In the same period of time, the Antimonopoly Office of the Slovak Republic $^{3}$ (hereinafter: AMO) adopted 31 antitrust decisions ${ }^{4}$. One decision

1 Available at: http://ec.europa.eu/competition/cartels/statistics/statistics.pdf (access 09.06.2019).

2 This amount includes corrections following amendment decisions of the General Court and the Court of Justice.

3 The AMO is the authority responsible in Slovakia for the protection and enforcement of national competition law as well as European competition law according the Council Regulation (EC) No 1/2003 of 16.12.2002 on the implementation of the rules on competition laid down in Articles 81 and 82 of the Treaty (OJ L 1, 4.1.2003, p. 1-25)

4 Available at: https://www.antimon.gov.sk/73-sk/prehlad-pripadov/?\&art_typ[]=1\&art_typ[] $=2 \&$ art_typ[] $=3 \&$ art_datum_rozhodnutie_od $=1.1 .2015 \&$ art_datum_rozhodnutie_do $=16.05 .2019$ \&page $=0$ (access 09 June 2019). 
was on an abuse on a dominant position according to Article 102 (a) of the Treaty on functioning of the European Union (hereinafter: TFEU) and Article 8 Section 2 (a) of the Act No. 136/2001 Coll. on the Protection of Competition, as amended (hereinafter: the Competition Act) ${ }^{5}$ containing an imposed fine of $127000 € .6$ Nine of the decisions were on the inapplicability of the cartel-forbidding Article 4 of the Competition $\mathrm{Act}^{7}$. In seven decisions the AMO accepted commitments submitted by competitors (MIKONA ${ }^{8}$, OPEL $^{9}$, ŠKODA Auto ${ }^{10}$, Mazda Motor ${ }^{11}$, Honda Motor ${ }^{12}$, Porsche Slovakia ${ }^{13}$, Toyota Central Europe Slovakia ${ }^{14}$ ). In fourteen decisions, the AMO imposed fines of a total amount exceeding $12200000 € .{ }^{15}$ Seven of these decisions were related to cartel agreements concluded in public procurement; the AMO imposed here also, beside financial sanctions, bans on the participation in public procurement procedures lasting from one to three years from the final decision. The rest of the decisions contained settlements or leniency.

From these facts we can conclude that the responsibility for securing a fair business environment stays with the market regulators. ${ }^{16}$ The AMO remains the most important national market regulator.

The objective of Directive (EU) 2019/1 of the European Parliament and of the Council of 11 December 2018 to empower the competition authorities of the Member States to be more effective enforcers and to ensure the proper functioning of the internal market (hereinafter: Directive 2019/1), as specified in para. 3 of its Recital, is to ensure that national competition 2019/1.

5 The Competition Act is a 'national competition law' within the meaning of the Directive

6 Decision of the AMO of 18.01.2018, No. 2018/DOZ/POK/2/2 Airport Bratislava (BTS).

7 Decisions of the AMO in cases No. 68/2017/OKT-2017/ZK/1/1/004 EUCOS-Build Systems-Brick-Box Engineering from 02.02.2017; No. 2016/ZK/1/1/014 GMT-Molior-Jagespiš from 31.03.2016; No. 2016/ZK/1/1/013 BOSO - Krovbav from 30.03.2016; No. 2016/ZK/1/1/010 STM Power - Škoda Slovakia from 8 March 2016; No. 2016/ZK/1/1/041 Edmart - IMH-Capgemini Slovensko-MW Consulting - Ernst \& Young - Bank Pro Soft from 11.08.2016; No. 2016/ZK/1/1/054 GRUND - Popad'ák - JAGI from 15.12.2016; No. 2016/ZK/1/1/006 DSC-ELORA-UNIOS-MARINE-ALUSTEEL from 26.02.2016 and No. 2016/ZK/1/1/051 Slovenská banková asociácia from 8.11.2016.

8 Decision of the AMO of 02.06.2017, No. 188/2017/OZDPaVD-2017/KV/2/1/015.

9 Decision of the AMO of 24.05.2017, No. 89/2017/OZDPaVD-2017/KV/2/1/014.

10 Decision of the AMO of 27.05.2016, No. 2016/KV/2/1/021.

11 Decision of the AMO of 07.06.2016, No. 2016/KV/2/1/027.

12 Decision of the AMO of 07.06.2016, No. 2016/KV/2/1/026.

13 Decision of the AMO of 27.05.2015, No. 2016/KV/2/1/020.

14 Decision of the AMO of 30.05.2016, No. 2016/KV/2/1/023.

15 As fines in decision of 12.04.2018 No. 2018/DOV/POK/R/8 were anonymised, we do not know the exact number of total amounts of all imposed fines.

16 e.g. AMO, Public Procurement Office for public markets, National Bank of the Slovak Republic for the banking sector. 
authorities have the guarantees of independence, resources, as well as enforcement and fining powers necessary to apply Articles 101 and 102 TFEU in the standards recognised in the (centralised) EU enforcement procedure and confirmed by the case law of the Court of Justice of the EU as well as European Court of Human Rights. Therefore, the first goal of this article is to analyse the state-of-the-art situation in Slovak competition law regarding the safeguards of the procedure in comparison with Directive 2019/1. The conflict of interest will be the second object of the author's research. This part includes the comparison with legislation of other administrative procedures and assessment whether current competition legislation needs to improve or is sufficient. Lastly, as Directive 2019/1 stressed the necessity to fight with the attempts of undertakings to avoid their responsibility for the breaches of competition law by realizing restructuralization operations, this and the effectiveness of enforcement are objects of author's research, too. When examining effectiveness, the author pays attention also to other aspects of the (in) effectiveness of enforcement, such as the incompatible interpretation of the term 'undertaking' in Slovak law or useless ('toothless') criminal legislation.

The author has selected these aspects of Directive 2019/1 as she considered them to be the most important parts of the procedure of competition law enforcement and both legislation and the case law calls for their conformity. Failure of a competition authority to meet the safeguard requirements will likely lead to the annulment of its decision. An insufficient assessment of the conflict of interest is capable of breaching the principle of sound administration, and may lead not only to unfair decisions taken by a competition authority, but also to damages caused by maladministration. Besides that, enforcement of competition law in Slovakia might be weakened by non-complying terminology, or by the lack of deterrent (or any other) effect of criminal sanctions. On the other side, even if the competition enforcement procedure meets all legal requirements, the goal of competition protection might not be met, as the competitor sometimes is able to avoid negative consequences of its behaviour. This scenario has already appeared in Slovakia in the recent past and caused a huge public outrage. The author, therefore, tested compliance of Slovak law with these challenges.

In this article, the author does not analyse the independence of the competition authority from the point of its creation or financing, as these questions are the subject of analysis of another author in this publication (Patakyová 2019B). The author neither analyses other aspects of Directive 2019/1, as they do not appear to be problematic when applying competition law in the Slovak Republic and already comply with current European Competition Law. 
During the research, the author used scientific methods such as analysis, comparison, deduction, and synthesis.

\section{Safeguards: State-of-the-art situation in Slovakia}

This part analyses the compatibility of Slovak law with the requirements set in Article 3 of Directive 2019/1, which stipulates:

(1) Proceedings concerning infringements of Article 101 or 102 TFEU, including the exercise of the powers referred to in this Directive by national competition authorities, shall comply with general principles of Union law and the Charter of Fundamental Rights of the European Union.

(2) Member States shall ensure that the exercise of the powers referred to in paragraph 1 is subject to appropriate safeguards in respect of the undertakings' rights of defence, including the right to be heard and the right to an effective remedy before a tribunal.

(3) Member States shall ensure that enforcement proceedings of national competition authorities are conducted within a reasonable timeframe. Member States shall ensure that, prior to taking a decision pursuant to Article 10 of this Directive, national competition authorities adopt a statement of objections.'

General principles of the European Union Competition Law can be found in various sources: the Treaty on European Union introduces the principle of the internal market (Article 3). The Treaty on Functioning of the European Union establishes the prohibition of cartel agreements, decisions by associations of undertakings and concerted practices, which may affect trade between Member States and which have as their object or effect the prevention, restriction or distortion of competition within the internal market (Article 101) and the prohibition of abuse of a dominant position within the internal market or its substantial part, if it may affect trade between Member States (Article 102). The principle of the protection of competition can be found in Protocol (No 27) on the Internal Market and Competition.

The Charter of Fundamental Rights of the European Union (hereinafter: Charter) introduces to the process of competition law enforcement limits for competition authorities and safeguards for competitors expressed in their right to privacy (Article 7), right to good administration ${ }^{17}$ (Article 41), right to an effective remedy and to a fair trial (Article 47), right of defence (Article 48).

17 Right to good administration includes also the right of every person to be heard, before any individual measure which would affect him/her adversely is taken, right to have access to his/her file (while respecting the legitimate interests of confidentiality and of professional and business secrecy) and the obligation of the administration to give reasons for its decisions. 
The Charter's provisions are applicable not only to the proceedings carried out by the Commission but also to the proceedings carried out by national competition authorities under Articles 101-102 TFEU (Bernatt, 2012, p. 257). As these rights are recognised also in Article 6 of the Convention for the Protection of Human Rights and Fundamental Freedoms (hereinafter: ECHR), whose contractual parties are all EU Member States, these principles are applicable to the enforcement of national legislation, too.

In addition, the above mentioned written principles are supplemented by general principles developed and used by the Court of Justice of the EU. Among important general principles recognised by European case law are: proportionality, legal certainty, legitimate expectation, respect for institutional balance and acquired rights (Tosato, 2015, p. 3).

The Slovak Competition Act does not contain specific rules on administrative proceedings. Competition law administrative proceedings are therefore governed by the rules contained in administrative lex generalis, that is, the Administrative Code ${ }^{18}$. Pursuant to Article 3 of the Administrative Code, the AMO as an administrative authority shall act in accordance with law and other regulations. It is obliged to protect the interests of the state (which is the competition) and the society (further development of competition to the benefits of consumers), the rights and interests of natural persons and legal entities and to strictly require the fulfilment of their duties. The AMO shall proceed in close cooperation with the parties and other concerned persons and always give them the opportunity to an effective defence of their rights and interests, in particular to comment on the basis of the decision and to exercise the right to make suggestions. The AMO shall assist and advice the parties or concerned persons so that they do not suffer harm in the proceedings due to the lack of knowledge of the law. Further, the AMO shall conscientiously and responsibly deal with every issue that matters in the proceedings, act in time and without undue delay and to use the most appropriate means to solve the case. The AMO shall ensure that the proceedings are conducted in an effective way and without unnecessary burdens to the parties or other persons. The decision of the AMO must be based on a reliably established basis. There shall be no unjustified differences in decisions on identical or similar cases.

National administrative principles are supplemented by European competition ones. The application of EU principles of competition proceedings is regularly realised by the decisional practice of the AMO, and later confirmed by the case law of the Supreme Court of the Slovak republic (hereinafter: SCSR). Moreover, the SCSR decided in case $\check{Z} \boldsymbol{S} \boldsymbol{R}^{19}$ that even in a special administrative procedure, which explicitly excludes the applicability

\footnotetext{
18 Act. No 71/1967 Coll on Administrative Proceedings (Administrative Code).

19 Judgement of the SCSR of 24.05.2017,3SžF/38/2015 ŽSR, ECLI:SK:NSSR:2017:1013200158.1.
} 
of an Administrative Order (for example inspection under the Competition Act, public procurement), Article 41 of the Charter of Fundamental Rights of the European Union, as well as Recommendation CM/Rec (2007) 7 of the Committee of Ministers to member states on good administration, must be taken into consideration. ${ }^{20}$ Thus, the SCSR by this extensive interpretation admitted the applicability of $\mathbf{E U}$ administrative principles to all national areas of administrative law. When regarding inspections, the SCRS in case Capgemini $^{21}$ then specified that the AMO, as the authority which, while exercising its competences, inevitably interferes with the rights and legally protected interests of the persons, shall take particular consideration to the compliance of its procedures with the principles of legality, legitimacy and proportionality. The AMO therefore is obliged to

- prepare the inspection soundly,

- define its subject matter properly,

- reason its mandates,

- request the court for the order for the inspection (if applicable),

- prepare, plan and exercise its procedures in compliance with the principle of legality and proportionality

in such a way, that it can obtain information legally and can use it with the legitimate aim within administrative proceedings realised within a reasonable time. The AMO shall conform its procedures with the requirements of the Constitution of the Slovak Republic as well as the ECHR.

When regarding the right of defence, it should be noted that the observance of the right of defence is a general principle of European Union law, which applies where the authorities are minded to adopt a measure which will adversely affect an individual. ${ }^{22}$ As the Court of Justice of the European Union (hereinafter: CJEU) stated for instance in the Toshiba case ch $^{23}$ 'rights of the defence requires that the undertaking concerned must have been afforded the opportunity, during the administrative procedure, to make known its views on the truth and relevance of the facts and circumstances alleged and on the documents used by the Commission to support its claim that there has been an infringement of the Treaty.'

${ }^{20}$ It is based on respect to principles of lawfulness, equality, impartiality, proportionality, legal certainty, principle of taking action within a reasonable time, participation, respect of privacy and principle of transparency.

21 Judgement of the SCSR of 28.04.2016, No 8Sžnz/2/2015-221 Capgemini Slovensko, ECLI:SK:NSSR:2016:9015898694.3.

22 Judgement of the Court of 16.01.2019, Case C-265/17 P UPS, ECLI:EU:C:2019:23, point 28.

23 Judgement of the Court of 06.07.2017, Case C-180/16 P Toshiba, ECLI:EU:C:2017:520, point 30 . 
The right of defence in Slovak competition law is guaranteed. Firstly, pursuant to Section 25 para. 6 of the Competition Act, the AMO shall instruct the parties, who are not legally represented by an attorney at law, on their procedural rights and obligations in order not to suffer harm during the procedure due to the lack of knowledge of the law. Therefore, the AMO through the guidance published on its website ${ }^{24}$ informs the wider public on rights and duties of the undertaking during an inspection. Undertakings' rights in this guidance include the right to call for legal assistance ${ }^{25}$, legal professional privilege ${ }^{26}$, right to exclude data of private character from the inquiry, right to be present at the verification of the privacy of such data, right to ask for interpretation or consult the execution of the order if its content is not clear.

Except its website, the AMO instructs undertakings on their rights also individually, within the document 'Notification of administrative proceedings ${ }^{27}$ '. As there is no interpreting provision in Slovak law on the content of such notification, nor relevant case law of the Slovak courts on this topic, the author would like to point to the judgement of the Czech Administrative Supreme Court in PHARMOS and $o^{28}$ where the court established:

It has to be clear from the Notification of administrative proceedings (i.e. from the very first act realised by the administrative authority in administrative sanctioning proceeding, which started ex officio) the content and scope of the "charges" within the meaning of the Article 6 ECHR and what behaviour/acts will be assessed within the proceedings.

Defining the content of a proceeding together with the instruction on procedural rights of the party creates a solid basis for the party to exercise his right to defence properly.

24 AMO: Usmernenie k právomoci Protimonopolného úradu Slovenskej republiky vykonávat inšpekcie. Available at: https://www.antimon.gov.sk/data/files/489_usmernenie-k-pravomoci-pro timonopolneho-uradu-slovenskej-republiky-vykonavat-inspekcie.pdf.

25 Representative of the undertaking or its lawyer has the right to be present at all actions taken by the AMO related to the inspection both in the premises of the undertaking and the premises of AMO.

${ }^{26}$ If the person concerned claims that a copy of the data includes communication with a lawyer, inspector may request him to specify this communication (e.g. by indicating its location, addressees and recipients of the communication) and justify why it should be treated as confidential. The indication of the data as confidential does not preclude inspectors from verifying whether such information has really the proclaimed character.

27 Pursuant to the Article 18(3) of the Administrative Code, the AMO shall inform all the known parties that the proceeding were opened.

28 Supreme Administrative Court of the Czech Republic of 31.03.2010, No1 Afs/58/2009-514 PHARMOS and o., para 8. 
By the way, there is currently no case law in Slovakia on the question of the right of defence or its aspects. Despite the fact that the question of legal professional privilege was raised in the case $\check{S} E V T^{29}$, the SCSR did not decide on its merit as it established the whole inspection of the AMO unlawful on other basis.

As administrative law did not expressively stipulate the principle against self-incrimination or the presumption of innocence, an undertaking concerned needs to seek general protection in the constitutional framework ${ }^{30}$ and the case law of the CJEU and the ECtHR. As in the previous case, there is no relevant case law of Slovak courts in these matters.

The right to be heard, as other procedural safeguard, is explicitly stipulated in Section 33 of the Competition Act, ${ }^{31}$ which obliges the AMO to call parties of the proceedings, before adopting a decision, for oral or written statement on its background and the way of its finding, or to propose its completion. An oral statement can be provided at an oral hearing. However, an oral hearing will be held only if the party requests it (the AMO is not obliged to hold an oral hearing without request of the party). Pursuant the Article 21(3) of the Administrative Code, such hearing shall not be public. The AMO is obliged to provide parties with information on the conclusions of the realised inquiry. Such a provision of information (hereinafter: statement) has the character equivalent to the Commission's statement of objections. The AMO shall describe all evidence that it has at its disposal and give its preliminary findings. The AMO shall thereafter follow these findings in its final decision. If the AMO intends to diverge from them (for example upon the evidence provided by the party) it shall send a new statement to the parties. As in previous cases, there is no relevant case law of Slovak courts in these matters.

Inquired parties and their representatives have also the right to access the file, make extracts, receive copies or electronic versions of all documents except for voting minutes. If documents in the file contain confidential information, classified information, bank secrets, tax secrets, business secrets, telecommunication secrets, postal secrets or confidentiality set upon the law, the AMO is obliged to adopt adequate measure for their protection.

29 Judgement of the SCSR of 05.04.2011, No 3Š̌/1/2011 ̌̌ EVT.

${ }^{30}$ Pursuant to the Article 47 (1) of the Constitution of the Slovak Republic 'Everyone shall have the right to refuse to give testimony, which might cause a danger of criminal proceedings against that person or a person akin.' Pursuant to the Article 50(2) 'Everyone, against whom a criminal proceeding is held, shall be deemed innocent until the court state his guilt with the final judgement'.

31 'Before issuing a final decision, the AMO is required to invite the parties to the proceedings to express in oral or written form their views on the substance and method of the decision or propose an amendment thereto, as well as to inform them on the finding of the investigation, which the Office has reached on the basis of available information and documents.' 
The AMO has set out a detailed technique of accessing the file for the party, its representative or other persons in its 2018 Guidelines on access to the files. ${ }^{32}$

As the AMO serves as the 'prosecutor', 'plaintiff' and 'judge' in one, a guarantee of the right to an effective remedy before a tribunal is inevitable and crucial. Access to judicial protection in Slovak administrative law is, with regards to the access to the judicial protection of the CJEU, relatively easy, as reviewable are not only decisions, but also any administrative actions of the administrative bodies by which rights, legally protected interests or duties of the persons are, or might be directly affected (Patakyová, 2019A, p. 150). The right to an effective remedy before a tribunal is governed by the Act No 162/2015 Coll Administrative Judicial Code (hereinafter: AJC). According the AJC, a party or any person affected by a decision or action of the AMO is entitled to seek judicial review of such act thorough a (general) administrative action under section 177 of the AJC, or through an administrative action in the matters of administrative sanctions under section 194 of the AJC or through an action against other intervention of the AMO under Section 252 of the AJC as follows. The Regional Court of Bratislava is the court competent for the procedure on these actions at first instance, which covers the territory of the whole Slovak Republic. The decisions of this court are reviewable upon cassation complaints, on which the Supreme Court of the Slovak republic is competent to decide.

In administrative judicial review two types of jurisdictions occur. Administrative courts have limited jurisdiction when deciding on the existence of a breach of competition law. Only the AMO has exclusive power to state that an undertaking breaches Article 101 TFEU/Section 4 of the Competition Act or Article 102/ Section 8 of the Competition Act. Pursuant to Section 191 AJC, court by a judgement will annul the decision or administrative action of the AMO if:

- it was based on an incorrect legal assessment;

- it is not reviewable due to the absence of intelligibility or lack of reasoning;

- factual findings of the AMO were insufficient to a proper assessment of the case;

- factual findings, which the AMO took into consideration as the basis of the reviewed decision are inconsistent with administrative case files;

- during the procedure, there has been substantial breach of administrative procedural provisions, which may cause the issue of unlawful decision.

As the SCSR explained in its judgement in $\operatorname{Cargo}^{33}$, the role of the court in administrative judiciary is not to replace the activity of administrative

32 AMO: Metodické usmernenie upravujúce administratívno-technické podmienky nazerania do spisov a vyhotovovanie výpisov, odpisov a kópiíz nich pre účastnikov konania a ich zástupcov, prípadne iné oprávnené osoby. Available at: https://www.antimon.gov.sk/data/files/915_mu-nazeranie-dospisov-pre-ucastnikov-konania.pdf (access 10.06.2019).

33 Judgement of the SCSR of 26.10.2010, No 1Sžhpu/2/2008 Cargo, p. 19. 
authorities, but to review the legality of their decisions, that is, to assess whether administrative authorities complied with statutory obligations. The court merely examines whether the discretion of the AMO is outside the limits and the aspects laid down by law, whether it is in accordance with the rules of logical thinking, and whether the basis for such decision has been fully and properly established by the procedural procedure. If these assumptions are met, the court cannot assume from the same facts other or opposite conclusions.

When the court, after the assessment of the decision or administrative action of the AMO, concludes that the action for annulment is not justified, it rejects such motion by way of the judgement. If the action was justified, the court will cancel such decision of the AMO. Depending on circumstances, in the case of cancelling the decision of the AMO, the court may, upon the request of the claimant, cancel even the decision of the AMO of lower instance in this case and at the same time to decide, that the AMO is obliged to proceed and decide again in this case. The AMO is bound by the legal opinion of the administrative court expressed in the cancelling decision. To ensure the effectiveness of the procedure, if the AMO did not follow the legal opinion of the administrative court, and the administrative court (due to the same reasons) cancelled the decision of the AMO again, the administrative court is entitled to impose a fine onto the AMO.

What needs to be stressed is that the scope of above mentioned judicial review of the procedure before the AMO or its decisions is limited to the scope and reasons provided by the claimant in his action.

A different situation occurs in the area of sanctioning, where the court exercises unlimited jurisdiction. Pursuant to Section 195 AJC, in the field of administrative sanctions, an administrative court is not bound by the scope and reasons of the claimant's action, if

- factual findings of the AMO were insufficient to a proper assessment of the case, or factual findings, which AMO took into consideration as the basis of the reviewed decision are inconsistent with administrative case files,

- the question of the forfeiture of responsibility for an offense or the expiry of a preclusive period or period of limitation for the imposition of sanctions for an offense may be inferred;

- it is the case of application of fundamental principles of criminal procedure under the Code of Criminal Procedure, which need to be applied on administrative sanctioning;

- it is the case of application of the principles of punishment under the Criminal Code, which need to be applied while imposing administrative sanctions;

- there needs to be an assessment whether the imposed type of sanction and its amount did not depart from the scope of discretion of the AMO. 
Administrative court, while reviewing an AMO decision, follows the factual basis ascertained by the AMO, but is entitled to supplement the evidence. Both parties, the AMO or an undertaking concerned, may request such evidence supplementation, but the court is not bound by such claim. Upon the basis of the assessed evidence and the motion of the claimant, the administrative court will decide by a judgement in two possibly ways. Firstly, it can decide on the change of type or amount of the sanction, even in case that the AMO did not excess the limit of its discretion. Such change can be made if imposed sanction is not proportionate to the committed offense or has liquidation character for the undertaking. The SCRS decided in this way in eD'system Slovakia ${ }^{34}$, where it lowered the imposed fine of the AMO of the amount of $1246621 €$ to the amount of $124622,10 €$. The court pointed out in this case, that sanction should be imposed is such a way, that its reimbursement is not negligible to the entity, but entity is still able to pay it. In this context, the court also referred to the case law of the CJEU (joined cases C-189/02 P, C-202/08 P, C-205/02 P, C-208/02 P and C-213/02 Dansk Rorindustri A/S and Others against the European Commission) which justifies the need to impose sanctions that entities will be able to pay.

Secondly, an administrative court may decide on giving up on imposing a sanction in a given case, if the purpose of administrative sanctioning might be achieved just by the processing of the case. In competition law cases, an administrative court may decide within the scope of sanctions defined in the Competition Act. At the same time, if the claimant is an undertaking concerned by a decision of the AMO, an administrative court cannot decide to the disadvantage of the claimant. By the way, there is no relevant case law in this matter.

It may occur that such legislation will introduce to the Slovak administrative sanctioning an automatic application of the principles of criminal sanctioning, but this issue is subject to an academic discourse. Košičiarová (2016) claims, that the AJC has bound administrative courts and therefore also administrative authorities (the AMO included) in the matters of administrative sanctioning to apply principles under criminal law without regard to the categorisation of the administrative offenses. On the other side, Šabová (2019) opposes this opinion with the following reasoning: Firstly, the AJC as a part of civil procedural law is not capable to regulate the duties of administrative authorities in administrative procedure. Even if the AJC regulates procedure and duties of administrative authorities during the judicial review of their decisions, it is not empowered to introduce procedural regulations for administrative procedure, nor regulations for sanctioning. Even more, the AJC, in the above mentioned

34 Judgement of the SCSR of 26.10.2016 No 8Sžhk/1/2016 eD'system Slovakia, ECLI:SK:NSSR:2017:1015200916.1. 
Section 195, did not specify which particular principle(s) of criminal law should be taken into consideration when imposing sanctions. As (towards the usage of principles) it stipulates: 'which need to be applied', it means, that the application of the particular principle(s) must be assessed individually in every case. To this question, the author agrees with the Šabová. Such approach conforms with the approach of the ECtHR, which assesses every case under the Engel $^{35}$ criteria (the nature of the offence and the degree of stigma attached to it, the severity of the possible penalty, and the classification of the offence under domestic law) to define, whether the autonomous concept of the term 'criminal charge' and the relating criminal principles will be applicable.

To sum up this part, we can conclude that the current Slovak legislation does not contradict the goals set up in Article 3 of Directive 2019/1 and the set goals are met before their transposition. However, these goals are met not thanks to precise and clear legislation, but mostly due to the EU-conforming attitude of the AMO and courts, who follow the case law of the CJEU and ECtHR. As the AMO instructs parties only in a general way on their rights and mostly by the citation of their rights explicitly stipulated in the legislation, 'advanced' defence of a party (referring to the right to fair trial and its principles emanating from the case-law of the CJEU and ECtHR) relies on the skills, knowledge and activity of that party's lawyer. As courts have, when reviewing the procedural aspects of the proceedings, only limited jurisdiction and can act only upon the action of the party and within the scope of its claim, precise formulation of the safeguards and applicable procedural principles in the Competition Act or its implementing regulation would therefore help legal certainty of the procedural parties.

\section{Conflict of interest in Antitrust law}

'Conflict of interest' is a negative phenomenon that is generally prohibited. But what does this term mean? Despite the fact, that we can find various definitions of conflict of interest in various EU legal sources, ${ }^{36}$ competition

35 Judgement of the ECtHR of 08.06.1976, No. 5100/71, 5101/71, 5102/71, 5354/72 Engel and others $v$ The Netherlands, ECLI:CE:ECHR:1976:0608JUD000510071 or Judgement of ECtHR of 21.05.2003, No. 34619/97 Janosevic v Sweden, ECLI:CE:ECHR:2002:0723JUD003461997.

36 For example, Regulation (EU) 2018/1046 on the financial rules applicable to the general budget of the Union stipulates, states that conflict of interests exists where the impartial and objective exercise of the functions of a financial actor or other persons including national authorities at any level, involved in budget implementation under direct, indirect and shared management, including acts preparatory thereto, audit or control, is compromised for reasons 
law is not one of them. For the purposes of general public service, we can use the definition provided by the OECD:

A "conflict of interest" involves a conflict between the public duty and private interests of a public official, in which the public official has private-capacity interests which could improperly influence the performance of their official duties and responsibilities. ${ }^{37}$

Directive 2019/1 in its recital ${ }^{38}$ recommends national administrative competition authority to publish a code of conduct that covers rules on a conflict of interest. In Article 4(2), it stipulates that Member States shall ensure that the staff and persons who take decisions exercising the powers to find and terminate infringements, impose interim measures, accept commitments and impose fines and penalties in national administrative competition authorities refrain from taking any action which is incompatible with the performance of their duties and/or with the exercise of their powers for the application of Articles 101 and 102 TFEU and are subject to procedures that ensure that, for a reasonable period after leaving office, they refrain from dealing with enforcement proceedings that could give rise to conflicts of interest.

The Slovak Competition Act contains the prohibition of conflict of interest only in relation with the trustee established by the AMO with the purpose to supervise the fulfilment of the conditions and obligations attached to a decision allowing a concentration ${ }^{39}$. Therefore, the Administrative Code (Section 9) must be applied again in a subsidiary fashion. An employee of the AMO is excluded from hearing and deciding a case if, having relation to the case, the parties to the proceedings or their representatives, there exists

involving family, emotional life, political or national affinity, economic interest or any other direct or indirect personal interest.

According to Article 24 of the Directive 2014/24/EU on public procurement the concept of conflicts of interest shall at least cover any situation where staff members of the contracting authority or of a procurement service provider acting on behalf of the contracting authority who are involved in the conduct of the procurement procedure or may influence the outcome of that procedure have, directly or indirectly, a financial, economic or other personal interest which might be perceived to compromise their impartiality and independence in the context of the procurement procedure.

Judgement of the Court of 12.03.2015, Case C-538/13 eVigilo, ECLI:EU:C:2015:166, point 35: 'A conflict of interests entails the risk that the contracting authority may choose to be guided by considerations unrelated to the contract in question and that on account of that fact alone preference may be given to a tenderer'.

37 OECD: 'Managing Conflict of Interest in the Public Service. OECD Guidelines and Country experiences'. OECD Publication Service, Paris, 2003. Available at: https://www.oecd. org/governance/ethics/48994419.pdf (access 11.06.2019), p. 24.

38 para 21.

39 Section 12 (8) of the Competition Act. 
a doubt of his impartiality. Furthermore, any person who has taken part in the proceedings as an employee of the competition authority of a different instance is also excluded from such hearing and deciding (the AMO provides two instanced proceedings). A party to the proceedings shall inform the AMO of the reasons for exclusion the deciding employee as soon as the party finds out such reasons. When an employee gets to know of reasons capable of his exclusion, he immediately must inform his closest senior manager and provides only inevitable acts. If the AMO decided that its employee shall be excluded due to the existing conflict of interest, it must adopt an adequate measure for a fair course of the procedure.

Is this regulation sufficient? Not really, as it covers clearly only a few situations. As there is only a general clause, a lot of questions arise. How, for example, to assess the relation to the party? Must the party be a close relative or any relative? How far must the relative be removed from the party in order not to be seen as in relation with the decision maker? And what happens in a situation when a close relative or close person to the decision maker has a business connection with the party, or the statutory body of the party? Or are they friends? What happens if none of them (party and employee) tell the truth on their relationship?

To find a solution, we can look for inspiration to other legal areas. For example, Slovak Bankruptcy Act ${ }^{40}$ provides an exhaustive definition of related persons. Inspired by the design of the Bankruptcy Act, decision maker could be deemed related to the party if he:

- is or was the employee, statutory body or a member of the statutory body, manager, procurator, or member of the supervisory board of the party, or

- holds a qualified interest in the party, which is equal to at least $5 \%$ of the registered capital of the legal entity or the voting rights in the party, or the possibility to exercise control over the management of the party, or indirect interest (which means an interest held indirectly through legal entities, in which he holds a qualified interest).

- is or was the employee, statutory body or a member of the statutory body, manager, procurator or member of the supervisory board of the legal entity, which holds a qualified interest in the party, or

- is a person, who is close (namely ascendant or descendant in a direct line, sibling, spouse or other persons, to who the harm suffered by the party would feel as his own) to the party, or above-mentioned subjects.

40 Act No. 7/2005 Coll on bankruptcy and restructuralization and on change and amendment of other acts, see the Article 9. 
Other inspiration could be found in the OLAF's practical guide on identifying the conflict of interest in public procurement ${ }^{41}$, which explains the means how to identify, manage, prevent and sanction conflict of interest existing between a public procurer (its employees) and tendering competitors. According to the author, this scheme is applicable to the competition processes too. For the purpose of identifying a possible conflict of interest, the employees of the AMO shall provide the employer with the list of existing related persons. This list shall be updated annually, or earlier, when it is relevant. At the beginning of the procedure, every participating employee or cooperating person shall fill in a declaration of absence of conflict of interests. To follow the principle of transparency, the AMO shall issue a Conflict of interest policy guide or Code of Conduct on this matter.

Besides that, other effective tools to prevent a conflict of interest might include a sufficient salary and, at the same time, a deterrent consequence for the partiality process and decision making.

To sum up, current national competition regulation of the conflict of interest needs to be the subject of a legislative improvement to meet the intended goal of EU legislation. The legislative change shall cover a more precise definition of the conflict of interest. For example: the AMO or its employees in charge, including national authorities at any level, shall not take any action which may bring their own interests into conflict with those of protecting of competition. They shall also take appropriate measures to prevent a conflict of interests from arising in the functions under their responsibility and to address situations which may objectively be perceived as a conflict of interests. A conflict of interest exists where the impartial and objective exercise of the functions of a market regulator is compromised for reasons involving family, emotional life, political or national affinity, previous working connection realised in last 5 years, economic interest or any other direct or indirect personal interest. Such definition shall be supplemented by a Code of conduct of the AMO containing the above mentioned declarations, procedural protocols and sanctions, which shall be reflected also in the employment contracts of the employees of the AMO.

Regarding the conflict of interest, there is no relevant case law of the Slovak courts in this matter.

41 OLAF: Identifying conflicts of interests in public procurement procedures for structural actions. A practical guide for managers elaborated by a group of Member States' experts coordinated by OLAF's unit D2- Fraud Prevention. Available at: https://eufunds.gov.mt/en/ EU\%20Funds\%20Programmes/Migration\%20Funds/Documents/Presentations/2013_11_12\%20 Final\%20guide\%20on\%20conflict\%20of\%20interests.pdf (access 11.06.2019). 


\section{Effective enforcement?}

One of the reasons for the adoption of Directive 2019/1 was weak or ineffective enforcement of competition law which has occurred in some Member States. The lack of guarantees of independence, resources, as well as enforcement and fining powers for national competition authorities to be able to apply Articles 101 and 102 TFEU effectively, means that undertakings engaging in anti-competitive practices might be subject to ineffective enforcement.

This may be the case of Slovakia. Slovak competition law enforcement is realised through administrative law sanctions. The Slovak legal system provides also both criminal sanctions and private enforcement, but these possibilities are quite ineffective, mostly due to the time of the proceedings of competition enforcement.

For example, the Slovak Criminal Code $^{42}$ in Article 250 recognises as a crime 'Abuse of the participation on competition' ('To the imprisonment up to three years will be sentenced anyone who abuses the participation on competition by action conflicting with Competition law resulting in the qualified harm lat least $26600 € /$ caused to other competitor or jeopardize the running of other competitor's business'). However, no one was ever sentenced for this crime. The reasons for that can be found in the preconditions of criminal responsibility: (1) final judgement on the abuse of participation on competition and (2) final judgement on damages of amount at least $26600 €$. In Slovakia this means a process spanning many years. Competition proceedings often last, from their beginning until the final judgement, for 5 years ${ }^{43}$ and sometimes even 10 years $^{44}$ or more ${ }^{45}$. After establishing the responsibility of an undertaking for 'abusing the participation on competition', then another, at least 4-years proceedings (on damages) need to be successfully completed and, of course, such proceedings require the action of the victim. Only after having the relevant evidence (the final judgement on the breach of competition law and the final judgement on the damages), has the criminal proceeding against a particular natural person (not undertaking), whose responsibility for the breach of competition law and the suffered harm needs to be proven, the potential to finish with the declaration of someone's guilt. But this part also can last years until the final judgement. Without any deeper research, considering

42 Act No. 300/2005 Coll Criminal Code.

43 E.g. AKCENTA/VÚB case No. 2 Sžhpu/3/2011, Slovak Telecom case No 3Sžhpu/1/2012.

44 E.g AKCENTA/ČSOB case No. 3Sžh/1/2016 of 23.11.2017, ECLI:SK:NSSR:2017:1014200849.1.

45 E.g. Dialničný kartel case No 5Sžh/2/2015 of 2.11.2016 Dialničný kartel, ECLI:SK: NSSR:2016:9015898699.2. 
that no one was ever sentenced for this crime, it can be said, that criminal enforcement of competition law in Slovakia is almost 'mission impossible'.

Administrative sanctions therefore remain the main way of effective enforcement of competition law. Although the Slovak rules for imposing fines follow those of the European Union ${ }^{46}$, some disparities and problems still remain.

For example, the Slovak Competition Act provides a slightly different definition of the term 'undertaking'. Under the current Article 3(2) of the Competition Act, the term 'undertaking' ('podnik' within the EU definition and "podnikatel" in Slovakia) signifies an entrepreneur within the meaning of Article 2 of the Act No 513/1991 Coll Commercial Code ${ }^{47}$, as well as natural persons and legal persons, their associations and associations of these associations, with respect to their activities and conduct that are, or may be, related to competition, regardless of whether or not these activities and acts are aimed at making a profit. According to Slovak law, this term covers also undertakings when considering concentrations. Following the definition provided by the CJEU (any entity engaged in an economic activity, irrespective of its legal status and the way in which it is financed ${ }^{48}$ ), we can see the differences.

When considering these differences, the author agrees with Blažo (2016), that the divergence between the concepts of undertaking in European and Slovak law can lead to obstacles to effective application or to illogical 'fallback' solutions when the AMO tries to punish competition infringements, particularly cartels. These hurdles can appear not only during the parallel application of European and Slovak law, when the discrepancies are evident, but also within the application of Slovak competition law. A narrower delineation of the concept of an undertaking in Slovak competition law obliges the AMO to identify liability of every natural or legal person separately and impose sanctions on every natural or legal person separately, even in case where several persons belong to a single economic unit and, therefore, are considered one unit under EU Law. In particular, this issue is evident in the case of cartels that last for a longer period of time when the persons, representatives or legal subjectivity of the companies change during that time. ${ }^{49}$

46 See the Methodical guideline of the AMO available at: https:/www.antimon.gov.sk/data/ files/963_metodicky-pokyn-o-postupe-pri-urcovani-pokut_1-9-2018.pdf (access 11.06.2019).

47 I.e. entity registered in the Business register, person providing business activity under a trade license, person providing business activity under a license other than trade license, natural person providing agricultural production which is registered in a special register.

48 Judgement of the Court of 14.03.2019, Case C-724/17 Skanska and others, ECLI:EU:C: 2019:204, para. 36 .

49 E.g., in the GIS cartel, the AMO in decision of 14.08.2009, No. 2009/KH/R/2/035 imposed 16 separate sanctions. 
Legal definition of the term 'undertaking' provided in Article 2(1).10 of Directive $2019 / 1^{50}$ and its transposition to national law will be therefore a step forward in the right direction.

Other problematic issue of enforcement might be the possibility for undertakings to escape liability for fines by way of restructuring. In Slovakia, it is not rare for formerly rich and stable companies, after falling into troubles with state (mostly financial or tax) administration that impose huge fines on them, to became empty and insolvent during the administrative process (which together with judicial review may last 10 years). A typical scenario of such scheme is, that management during that time established in parallel a new company, often with a similar name, to which directly, or through secretly related subjects, transfer property and other valuables from the 'problematic' undertaking. The way how they provide these transfers are usually highly sophisticated, with the purpose not to fall to the competition concept of economic continuity, but be safe from any action from the potential bankruptcy trustee or any creditor contesting these transfers ${ }^{51}$. Such undertakings (or persons behind them) also ensure control for themselves over the bankruptcy procedure through the voting of 'friendly' creditors. According the Section 36 of the Bankruptcy Act, a bankruptcy trustee, who was established independently through a random choice of the electronic system provided by the court, can be revoked and altered by the majority of voting creditors on the first meeting of creditors to another (and 'right') one. This process might be connected even with bribery of the voting creditors. As this action is not considered to be a crime and the revoked bankruptcy trustee does not have the right to challenge such decision of the creditors to the judicial review, it represents an elegant way of escaping liability.

Another problem of enforcement relates to the extreme length of the procedure. Proceedings in Dialničný kartel ${ }^{52}$ lasted 12 years (from the inspection in 2004 until final judgement in 2016). The ineffectiveness of enforcement in this case is stressed by the fact, that this cartel had the form of bid rigging in public procurement. Despite the fact, that the former (2005) public procurement legislation and the current competition legislation recognise as a sanction for cartelists a ban on the participation in public tenders, public

50 'Undertaking' as referred to in Articles 101 and 102 TFEU, means any entity engaged in an economic activity, regardless of its legal status and the way in which it is financed.

51 According the Article 60 of the Bankruptcy Act, a bankruptcy trustee is entitled to contest any legal actions, by which the debtor stints its creditors, as long as the same are taken with the intention of the debtor to stint its creditors and such intentions was or must have been known to the other party. It shall only be possible to contest those penalizing actions by law, which were taken during five years prior to the passing of the bankruptcy order.

52 Judgement of the SCSR of 02.11.2016 No 5Sžh/2/2015 Dialničný kartel, ECLI:SK:NSSR: 2016:9015898699.2. 
authorities were not able to apply the ban in this case. As previous legislation stipulated, that tenderer is banned from public procurement for the period of 5 years after concluding the cartel (which in this case expired in 2009), which has to be confirmed by a final judgement, the recent legislation requires the imposition of the ban to the decision of the AMO (which is not the case, as the decision of the AMO was adopted in 2006 and the court cannot change the sanction to the disadvantage of the party if he is a claimant). During the whole process and also after the process, members of the cartels have been continuing to participate in tenders. To that regard, the Commission is likely to start an inquiry on an abuse of European Structural Funds, as the Slovak Republic did not prevent the participation of members of this cartel in various public procurements for construction works financed by European Funds..$^{53}$

As the Directive explains and requires the necessity of the adoption of adequate guarantees on the imposition of effective, proportionate and dissuasive fines on undertakings and associations of undertakings which infringe competition law, the above-mentioned issues shall be the subject of legislative changes.

Firstly, the application of compatible terminology is inevitable. An unification of the term 'undertaking' will have an impact not only to effective imposition of fines but also on effective private enforcement, especially when regarding the concept of economic unit in the light of the above mentioned SKANSKA.

Secondly, with the aim to prevent the possibility of an undertaking escaping easily through the bankruptcy and recovery system, it might be useful to establish personal responsibility of the owner or acting managers of the undertaking breaching competition law, if the imposed fines are not enforceable. Strengthening the position of bankruptcy trustees and reprobating the bribery of creditors in bankruptcy proceeding, can also help to better enforce competition law.

Thirdly, both the Administrative Code and Administrative Judicial Code require proceedings to conclude in reasonable time. Such legislation therefore follows the goals set up in Directive 2019/1. Effective enforcement therefore fails on human factors - overloading of the courts and obstructions of the parties. As administrative courts deal with the whole packet of administrative law (even social security law, construction law, tax law, environmental law, etc.), an effective way how to reduce the length of the judicial process might be found in the creation of specialised competition senates.

53 https://www.aktuality.sk/clanok/691446/opat-sa-vynoril-davny-dialnicny-kartel-siahnu-na m-na-eurofondy/ (accessed on 22.06.2019). 


\section{Conclusions}

This analysis is not an exhaustive comparison of all aspects of Slovak Competition Law with Directive 2019/1 as, generally, the Slovak system of competition procedure tends to be in line with the practice of the European Commission. The AMO and Slovak courts regularly rely on European case-law and the soft-law instruments of the European Commission even in purely national cases. We can therefore say that the practice at European level shapes the application of national level (Blažo, 2016).

However, this short analysis of particular issues proved that incompatible, problematic or at least weak parts of Slovak competition law still remain, which need legislative improvements to achieve the EU standard of enforcement.

Safeguards predicted in Article 3 of the Directive 2019/1 present the slightest problem. Right to defence, right to be heard, legal professional privilege, right to access the file, right to exclude private data from the file, right for an oral hearing, right to present evidence and make suggestions, principle against self-incrimination, presumption of innocence, right to good administration or right to an effective remedy before a tribunal - all of these principles can be found in Slovak legislation, relevant case law of the CJEU and ECtHR and recognised principles applicable in the Slovak legal system. Absence of relevant Slovak case law in this relation therefore might mean that the AMO properly applies these safeguards to its proceedings.

Regarding the requirement of Directive 2019/1 to effectively prevent conflict of interest, it has to be admitted that Slovakia's current legislation does not meet the set goal. Current provision on conflict of interest was formulated in 1976 and is easily avoidable. It neither provides any effective preventive measures for AMO employees (positive measures in the form of a sufficiently high salary and deterrent measures in the form of sanctions, such as an immediate termination of the employment contract). More precise regulation together with the AMO's guidance or code of conduct on identifying and processing the conflict of interests therefore might ensure transparency and (after all) the effectiveness of the enforcement process too.

As it can be deducted from the text above, the effective enforcement of competition law by the Slovak competition authorities might be considered to be the most problematic part of the analysed issues. Lack of compliance in terminology and the great length of proceedings are not the only, but simply the most serious issues to be solved. Obsolete provisions of the Criminal Code and a leaky system of bankruptcy rules also do not comply with the requirements of Directive 2019/1

Even if Directive 2019/1 shined a light on the (in)effectiveness of the enforcement of competition law by the national competition authorities and, 
therefore, with regard to future legislation amendments, it certainly represents another brick in empowering the Slovak market regulator.

\section{Literature}

Antimonopoly Office of the Slovak Republic: Metodické usmernenie upravujúce administratívno-technické podmienky nazerania do spisov a vyhotovovanie výpisov, odpisov a kópií z nich pre účastníkov konania a ich zástupcov, prípadne iné oprávnené osoby. Available at: https://www.antimon.gov.sk/data/files/915_mu-nazeranie-do-spisovpre-ucastnikov-konania.pdf.

Antimonopoly Office of the Slovak Republic: Metodický pokyn o postupe pri určovaní pokút v prípadoch zneužívania dominantného postavenia a dohôd obmedzujúcich sútaž. (2018). Available at: https://www.antimon.gov.sk/data/files/963_metodickypokyn-o-postupe-pri-urcovani-pokut_1-9-2018.pdf.

Antimonopoly Office of the Slovak Republic: Usmernenie k právomoci Protimonopolného úradu Slovenskej republiky vykonávat inšpekcie. Available at: https://www.antimon.gov. sk/data/files/489_usmernenie-k-pravomoci-protimonopolneho-uradu-slovenskej-repub liky-vykonavat-inspekcie.pdf.

Bernatt, M. (2012). Convergence of Procedural Standards in the European Competition Proceedings. In: The Competition Law Review, Volume 8 Issue 3, pp. 255-283. ISSN 1745-638X (online). Available at: http://new.clasf.org/CompLRev/Issues/Vol8Issue3 Art2Bernatt.pdf.

Blažo, O. (2016). The Legal Consequences of Breaching Competition Rules in the Slovak republic. In: The Procedural Aspects of the Application of Competition Law. European Frameworks - Central Europe Perspectives. Europa Law Publishing. Groningen. ISBN 978-90-8952-187-3.

Blažo, O. (2016). Administrative Competition Procedure and Judicial Review in the Slovak Republic. In: The Procedural Aspects of the Application of Competition Law. European Frameworks - Central Europe Perspectives. Europa Law Publishing. Groningen. 2016. ISBN 978-90-8952-187-3.

Blažo, O., Kalesná, K. (2012). Zákon o ochrane hospodárskej sútaže. Komentár. $1^{\text {st }}$ edition. C.H. Beck, Prague. ISBN: 978-80-7400-257-1.

Dannecker, G., Jansen O. (2004). Competition Law Sanctioning in the European Union. The EU-Law Influence on the National Law System of Sanctions in the European Area. Kluwer Law International. Hague. ISBN 90-411-2100-5.

Jones, A., Sufrin, B. (2011). EU Competition Law. $4^{\text {th }}$ edition. Oxford University Press. Oxford. ISBN 978-0-19-957273-1.

Košičiarová, S. (2016). Povinnost správneho súdu aplikovat trestnoprávne zásady vo veciach správneho trestania. Justičná revue, Vol. 68, 890-899.

OECD (2003). Managing Conflict of Interest in the Public Service. OECD Guidelines and county experiences. OECD Publications Service. Paris Cedex. ISBN 92-64-10489-5 Available at: https://www.oecd.org/governance/ethics/48994419.pdf.

OLAF: Identifying conflicts of interests in public procurement procedures for structural actions. A practical guide for managers elaborated by a group of Member States' experts coordinated 
by OLAF's unit D2- Fraud Prevention. Available at: https://eufunds.gov.mt/en/EU\%20 Funds\%20Programmes/Migration\%20Funds/Documents/Presentations/2013_11_12\%20 Final\%20guide $\% 20$ on $\% 20$ conflict $\% 20$ of $\% 20$ interests.pdf.

Patakyová, M.T. (2019A). Ludskoprávne aspekty hospodárskej sútaže. Antitrust z pohladu ludských práv. Wolters Kluwer. Bratislava. ISBN 978-80-571-0002-7.

Patakyová, M.T. (2019B). Independence of National Competition Authorities - Problem Solved by Directive 2019/1? Example of the Antimonopoly Office of the Slovak Republic, YARS, Vol. 12(20).

Potasch, P., Hašanová, J (2012). Zákon o správnom konaní (správny poriadok). Komentár. $1^{\text {st }}$ edition. C.H. Beck, Prague. ISBN: 978-80-7400-422-3.

Šabová, Z. (2019). Zásady správneho trestania v sútažnom práve. Právne noviny. 3 April 2019. Available at: https://www.pravnenoviny.sk/zasady-spravneho-trestaniav-sutaznom-prave\#_ftn7.

Tosato, G.L. (ed.), Bellodi L. (ed.) (2015). EU Competition Law. Volume 1: Procedure. Antitrust - Mergers - State Aid. Second edition, Deventher: Claeys\&Casteels Law Publishers. ISBN 9789077644195.

Tóth, T. (2018). Life after Menarini: The Conformity of the Hungarian Competition Law Enforcement System with Hungarian Rights Principles. Yearbook of Antitrust and Regulatory Studies, Vol. 2018, 11(18). DOI: 10.7172/1689-9024.YARS.2018.11.18.2. Available at: http://www.yars.wz.uw.edu.pl/yars2018_11_18/35.pdf.

Whish, R. and Bailey D. (2012). Competition Law.7th ed. Oxford: Oxford University Press. 